\title{
Synthesis, Characterization and Evaluation of Antimicrobial, Antioxidant \& Anticancer Activities of Copper Doped Zinc Oxide Nanoparticles
}

\author{
Saranya Rishikesan ${ }^{1}$ and Mubarak Ali Muhamath Basha ${ }^{2, \star}$ \\ ${ }^{1}$ Research and Development Centre, Department of Chemistry, Bharathiar University, Coimbatore - \\ 641 046, Tamilnadu, India. \\ ${ }^{2}$ Department of Chemistry, Chikkaiah Naicker College, Erode - 638 004, Tamil Nadu, India. \\ *Corresponding author: E-mail: mubarakscience@gmail.com \\ Contact Number: 091-9443312819
}

Received: 07-01-2019

\begin{abstract}
The present work reveals the influence of copper $(\mathrm{Cu})$ doping in band gap energy level as well as selective cytotoxicity of $\mathrm{ZnO}$ nanoparticles against human breast cancer cells (MCF7), human cervical carcinoma (HeLa), and one normal (Vero) cell line. $\mathrm{Cu}$-doped $\mathrm{ZnO}$ nanoparticles ( $\mathrm{Cu}-\mathrm{ZnO} \mathrm{NPs}$ ) were synthesized and validated by UV-Vis, FT-IR, XRD, SEM and EDAX. Cu-doping diminished the band gap energy of $\mathrm{ZnO}$ NPs from $3.54 \mathrm{eV}$ to $3.29 \mathrm{eV}$. Antimicrobial activity has been evaluated against three bacterial and fungal strains. Antioxidant activity was examined using a DPPH free radical, $\mathrm{ABTS}^{+}$radicals, hydroxyl radicals and nitric oxide scavenging assay. $\mathrm{Cu}-\mathrm{ZnO} \mathrm{NPs}$ showed anticancer activity with $\mathrm{IC}_{50}$ value of $219.56 \mu \mathrm{g} / \mathrm{mL}$ against MCF7 and $137.27 \mu \mathrm{g} / \mathrm{mL}$ against HeLa cell lines. The doping of Cu with $\mathrm{ZnO}$ improved the selective cytotoxicity of ZnO NPs towards MCF7 and HeLa cells without affecting the normal cells.
\end{abstract}

Keywords: $\mathrm{Cu}-\mathrm{ZnO}$ NPs, Antimicrobial activity, Cytotoxicity, MCF7, HeLa and Vero cell lines

\section{Introduction}

Cancer is a deadly disease which increases the mortality rate in the recent decades. Though the treatment of cancer by chemotherapy, radiation therapy and surgery were efficient towards the killing of cancer cells, it has an adverse effect towards the normal cells also. ${ }^{1-3}$ The importance of these therapies is now gradually diminished due to the advancement of nanomedicine, targeted drug delivery and multi-target inhibitors. ${ }^{4}$ Engineered nanoparticles (NPs) have advanced imaging, therapeutic activity and effective for early detection of cancer and cancer treatment. ${ }^{5-8}$ It has the additional benefits of active/passive targeting, high solubility/bioavailability, biocompatibility and multi-functionality over traditional cancer therapies. ${ }^{9} \mathrm{ZnO}$ nanoparticles have multiple properties including favorable band gap, electrostatic charge, large surface area and potentiation of redox-cycling cascades. ${ }^{10,11}$ These characteristics of $\mathrm{ZnO}$ nanoparticles are being exploited in biomedical field such as cell imaging, bio-sensing and drug delivery. Recently, $\mathrm{ZnO}$ nanoparticles receive much attention for their potential application in can- cer therapy. $\mathrm{ZnO}$ nanoparticles exhibited a preferential ability to kill human cancer cells as compared with normal cells. ${ }^{12,13} \mathrm{ZnO}$ nanoparticles have potential to develop as an anticancer candidate. The possible mechanism of cytotoxicity of $\mathrm{ZnO}$ NPs was associated with the occurrence of apoptosis. ${ }^{14}$ However, for practical therapeutic applications, new strategies are required to further improve the cancer killing ability of $\mathrm{ZnO}$ nanoparticles without affecting normal cells. This study focuses on improving the cancer cells killing ability of $\mathrm{ZnO}$ nanoparticles by metal ions doping.

As the functionality and efficiency of $\mathrm{ZnO}$ nanostructures can be improved by increasing and modifying their surface area by adding some dopants materials i.e. biomolecules and transition metals $(\mathrm{Mn}, \mathrm{Fe}, \mathrm{Cr}, \mathrm{Cu})$ at nanoscale. ${ }^{15,16}$ Through surface modification with biomolecules and transition metals, $\mathrm{ZnO}$ nanoparticles could be used as biosensors, antimicrobial, antioxidants, drug delivery systems and bio-imaging materials. ${ }^{16-18}$ Different methods have been developed for the fabrication of $\mathrm{ZnO}$ and transition metal doped $\mathrm{ZnO}$ nanoparticles. ${ }^{19}$ Among all the dopants, doping of $\mathrm{ZnO}$ NPs with $\mathrm{Cu}$ greatly alter 
the optical, morphological structural, magnetic, electrical, and biological properties of the $\mathrm{ZnO} N \mathrm{NPs}^{20,21} \mathrm{ZnO} \mathrm{NPs}$ doped with $\mathrm{Cu}$ have shown remarkable improvement in different properties i.e. electrical conductivity, ${ }^{22}$ magnetic, ${ }^{23}$ biological, ${ }^{24}$ gas sensing, ${ }^{25}$ optical properties and mechanical strength. ${ }^{26} \mathrm{Cu}$-doped $\mathrm{ZnO}$ NPs showed enhanced anticancer activity as compared to Un-doped $\mathrm{ZnO} N \mathrm{Ns}^{27}$

The present study aims on improving the anticancer activity of $\mathrm{ZnO}$ NPs by cationic doping. Especially, $\mathrm{Cu}$ was considered as one of the most effective doping elements for improving the anticancer activity of $\mathrm{ZnO}$ NPs. It was found that the doped $\mathrm{Cu}^{2+}$ ions with half-filled electronic configuration which contributed to the enhanced anticancer activity of $\mathrm{ZnO}$ nanoparticles. In order to verify the efficacy of copper doping with $\mathrm{ZnO}$ in various aspects an attempt was taken to investigate elaborately. Herein, we report the synthesis, characterization of $\mathrm{ZnO}$ and $\mathrm{Cu}-\mathrm{ZnO}$ nanoparticles and its antimicrobial, antioxidant and anticancer activities.

\section{Experimental}

\section{1. Materials}

All chemicals used were of analytical grade and used as received. Zinc sulphate heptahydrate $\left(\mathrm{ZnSO}_{4} \cdot 7 \mathrm{H}_{2} \mathrm{O}\right)$, Sodium hydroxide $(\mathrm{NaOH})$, Copper sulphate pentahydrate $\left(\mathrm{CuSO}_{4} \cdot 5 \mathrm{H}_{2} \mathrm{O}\right)$ were purchased from Merck and were used as received.

\section{2. Synthesis of $\mathrm{ZnO} \mathrm{NPs}$}

$\mathrm{ZnSO}_{4} \cdot 7 \mathrm{H}_{2} \mathrm{O}(0.4 \mathrm{M})$ and $\mathrm{NaOH}(0.8 \mathrm{M})$ were dissolved in distilled water. $\mathrm{ZnO}$ nanoparticles was prepared using co-precipitation method by dropwise addition of $\mathrm{NaOH}$ to $\mathrm{ZnSO}_{4} \cdot 7 \mathrm{H}_{2} \mathrm{O}$ with constant stirring at $80{ }^{\circ} \mathrm{C}$ until a white precipitate was formed. After cooling, the precipitate was washed several times with deionized water followed by ethanol and dried in a hot air over for $5 \mathrm{~h}$ at 80 ${ }^{\circ} \mathrm{C}$. The dried samples were calcined at $350{ }^{\circ} \mathrm{C}$ for $3 \mathrm{~h}$ to obtain the nano sized $\mathrm{ZnO}$.

\section{3. Synthesis of $\mathrm{Cu}-\mathrm{ZnO} \mathrm{NPs}$}

$\mathrm{ZnSO}_{4} \cdot 7 \mathrm{H}_{2} \mathrm{O}(0.8 \mathrm{M})$ was dissolved in deionized water. $\mathrm{Cu}-\mathrm{ZnO} \mathrm{NPs}$ were prepared by the drop wise addition of $\mathrm{NaOH}(0.8 \mathrm{M})$ solution and $\mathrm{CuSO}_{4} \cdot 5 \mathrm{H}_{2} \mathrm{O}(0.02$ M) solution to $\mathrm{ZnSO}_{4} \cdot 7 \mathrm{H}_{2} \mathrm{O}$ with constant stirring. The stirring was continued until the complete precipitation occurs. Before filtration the mother liquid was aged for $12 \mathrm{~h}$. The residue thus obtained was dried at $80^{\circ} \mathrm{C}$ for $12 \mathrm{~h}$ and calcined at $350^{\circ} \mathrm{C}$ for $3 \mathrm{~h}$.

\section{4. Characterization Methods}

The Ultra Violet-Visible-Diffuse reflectance spectroscopy (UV-Vis-DRS) measurements were performed with a JASCO V-550 double beam spectrophotometer with PMT detector. The samples were filled in a quart's cuvette of $1 \mathrm{~cm}$ light-path length, and the light absorption spectra were given in reference to deionized water. Surface structure was characterized by a Fourier Transform Infrared (FT-IR) spectrophotometer (JASCO-RT-IR-460 plus). The present study is restricted to the assignment of various vibrational modes of metal oxides compounds within the frequency range $400-4000 \mathrm{~cm}^{-1}$ and IR analysis was carried out for oven-dried samples. The sample for IR analysis was prepared by mixing $0.1 \mathrm{~g}$ of $\mathrm{KBr}$ with $0.003 \mathrm{~g}$ of sample and then pressing into a pellet. X-ray diffraction (XRD) patterns were collected at $25{ }^{\circ} \mathrm{C}$ using (XPERT-PRO-X$\mathrm{RAY}$ diffractometer with $\mathrm{Cu}-\mathrm{Ka}$ radiation and structural assignments were made with reference to the JCPDS powder diffraction files. Scanning electron microscopy (SEM) images were performed by JSM-6701F-6701 instrument in both back scattered electron modes. The elemental analysis was detected by an energy dispersive X-ray spectroscopy (EDX) attached to the SEM.

\section{5. Antimicrobial Activity}

Antibacterial and antifungal activities were evaluated for the synthesized $\mathrm{ZnO}$ and $\mathrm{Cu}-\mathrm{ZnO}$ NPs. The salt of $\mathrm{ZnSO}_{4} \cdot 7 \mathrm{H}_{2} \mathrm{O}, \mathrm{CuSO}_{4} \cdot 5 \mathrm{H}_{2} \mathrm{O}$ and the synthesized NPs of $\mathrm{ZnO}$ and $\mathrm{Cu}-\mathrm{ZnO}$ were tested to determine their antimicrobial activities against three bacterial strains namely $E$. coli (1B), S. aureus (2B) and P. aeruginosa (3B) and three fungal strains namely Aspergillus flavus ( $1 F)$, Candida albicans $(2 F)$ and Fusarium (3F). The samples were dissolved in dimethyl sulphoxide and it was made into the required concentrations. The bacterial strains as well as fungal strain were inoculated separately in $30 \mathrm{~mL}$ of nutrient broth in a conical flask and incubated for $24 \mathrm{~h}$ to get active strain by using well diffusion method. Muller Hinton agar was poured separately into petri dishes. After solidification $0.25 \mathrm{~mL}$ of test strains were inoculated in the media separately and care was taken to ensure proper homogenization. The experiment was performed under strict aseptic conditions. After the medium solidified, a well was made in the plates with sterile borer $(5 \mathrm{~mm})$. The $(40 \mu \mathrm{L})$ of the test sample was introduced into the well and plates were incubated at $37^{\circ} \mathrm{C}$ for $72 \mathrm{~h}$. All samples were tested in triplicates. Microbial growth was determined by measuring the diameter of zone of inhibition. Amikacin and Ketoconazole were used as control for antibacterial and antifungal activity assay respectively.

\section{5. 1. Determination of Minimum Inhibitory Concentration (MIC)}

A sterile 96 well plates were prepared under aseptic conditions. The freshly prepared sample suspensions in DMSO were sonicated using a sonicator. A volume of 100 $\mu \mathrm{L}$ of test material in $10 \% \mathrm{DMSO}$ (a stock concentration of 
$1 \mathrm{mg} / \mathrm{mL}$ for purified compounds) was pipetted into the first row of the plate. To all the other wells, $50 \mu \mathrm{L}$ of nutrient broth was added for bacteria cells and $50 \mu \mathrm{L}$ of Sabouraud dextrose broth for fungi cells, and serial dilutions were performed using a multichannel pipette. To each well, $10 \mu \mathrm{L}$ of resazurin indicator solution was added. Finally, $10 \mu \mathrm{L}$ of bacterial/fungal suspension $\left(5 \times 10^{6} \mathrm{cfu} /\right.$ $\mathrm{mL}$ ) was added to each well to achieve a concentration of 5 $\times 10^{5} \mathrm{cfu} / \mathrm{mL}$. The commercial drugs Amikacin (against bacteria) and Ketoconazole (against fungi) were used as a positive control. The plates were prepared in triplicate, and placed in an incubator set at $37^{\circ} \mathrm{C}$ for $18-24 \mathrm{~h}$ and the color change from purple to pink or colorless indicates the reduction of dye by the viable bacteria/fungi. The lowest concentration at which color change occurred was taken as the MIC value. The average of three values was calculated to get MIC values.

\section{6. Evaluation of Antioxidant Properties of the Compounds}

The remarkable antibacterial and antifungal activities of the synthesized $\mathrm{Cu}-\mathrm{ZnO}$ NPs induced us to study its radical scavenging properties. The radical scavenging activities of $\mathrm{Cu}-\mathrm{ZnO}$ NPs along with standard have been examined with reference to 2-20-diphenyl-1-picrylhydrazyl (DPPH) radicals, 2, 2'-azino-bis (3-ethyl benzothiazoline-6-sulfonic acid (ABTS) radicals, hydroxyl radicals $(\cdot \mathrm{OH})$ and nitric oxide (NO$\cdot)$ assay and the determination of $50 \%$ activity $\left(\mathrm{IC}_{50}\right)$ values.

\section{6. 1. DPPH free Radical Scavenging Assay}

The DPPH radical scavenging activity of $\mathrm{Cu}-\mathrm{ZnO}$ NPs was measured according to the method of Blios. ${ }^{28}$ The DPPH radical is a stable free radical having $\lambda_{\max }$ at $517 \mathrm{~nm}$. A variable concentration of the sample $(20-100 \mu \mathrm{g} / \mathrm{mL})$ were mixed with $1.0 \mathrm{~mL}$ of methanolic solution containing DPPH radicals, resulting in the final concentration of $\mathrm{DPPH}$ being $0.2 \mathrm{mM}$. The mixture was shaken vigorously and left to stand for $30 \mathrm{~min}$, and the absorbance was measured at $517 \mathrm{~nm}$. Vitamin E was used as control. The percentage of inhibition in DPPH radical scavenging activity was calculated as follows;

$$
\% \text { Inhibition }=\left(A_{0}-A_{1}\right) / A_{0} \times 100
$$

\section{6. 2. ABTS Cation Radical Scavenging Assay}

ABTS decolorization assay involves the generation of the $\mathrm{ABTS}^{+}$chromophore by the oxidation of ABTS with potassium persulphate. It is applicable for both hydrophilic and lipophilic compounds. The scavenging activity of $\mathrm{Cu}-\mathrm{ZnO}$ NPs on ABTS cation radical was measured at $734 \mathrm{~nm}$.

Equal volume of $7 \mathrm{mM}$ of ABTS was mixed with 2.45 $\mathrm{mM}$ potassium persulphate and the mixture was allowed to stand in the dark at room temperature for $12-16 \mathrm{~h}$ before use. ABTS ${ }^{+}$solution was diluted to an absorbance of $0.7 \pm 0.05$ with ethanol at $734 \mathrm{~nm}$. The reaction was initiated by the addition of $1.0 \mathrm{~mL}$ of diluted $\mathrm{ABTS}^{+}$to $10 \mu \mathrm{L}$ of different concentrations $(20-100 \mu \mathrm{g} / \mathrm{mL})$ of sample. Vitamin E was used as standard and positive control. The absorbance was read at $734 \mathrm{~nm}$ and the percentage inhibitions were calculated. The inhibition was calculated according to the equation,

$$
\mathrm{I}=\left(\mathrm{A}_{0}-\mathrm{A}_{1}\right) / \mathrm{A}_{0} \times 100
$$

Where, $A_{0}$ is absorbance of control reaction, $A_{1}$ is absorbance of test compound.

\section{6. 3. Hydroxyl Radical Scavenging Assay}

The hydroxyl radical scavenging activities of the compounds have been investigated using Nash method. ${ }^{29}$ A reaction mixture of $3.0 \mathrm{~mL}$ volume contained, $1.0 \mathrm{~mL}$ of $1.5 \mathrm{mM} \mathrm{FeSO}_{4}, 0.7 \mathrm{~mL}$ of $6 \mathrm{mM}$ hydrogen peroxide, 0.3 $\mathrm{mL}$ of $20 \mathrm{mM}$ sodium salicylate and $1.0 \mathrm{~mL}$ of different concentrations $(50-250 \mu \mathrm{g} / \mathrm{mL})$ of $\mathrm{Cu}-\mathrm{ZnO}$ NPs. After incubation for an hour at $37^{\circ} \mathrm{C}$, the absorbance of the hydroxylated salicylate complex was measured at $562 \mathrm{~nm}$. Vitamin E was used as positive control. The percentage scavenging effect was calculated as,

Scavenging activity $=\left[1-\left(A_{1}-A_{2}\right) / A_{0}\right] \times 100$

Where, $A_{0}$ is absorbance of the control, $A_{1}$ is absorbance in the presence of the extract; $A_{2}$ is absorbance without sodium salicylate.

\section{6. 4. Nitric Oxide (NO) Assay}

The amount of nitrite was determined by the literature method. ${ }^{30}$ The reaction mixture $(6.0 \mathrm{~mL})$ containing sodium nitroprusside $(4.0 \mathrm{~mL})$, phosphate buffer saline (PBS, $1.0 \mathrm{~mL}$ ) and different concentrations $(50-250 \mu \mathrm{g} /$ $\mathrm{mL})$ of a sample $(1.0 \mathrm{~mL})$ in DMSO was incubated at $25^{\circ} \mathrm{C}$ for 15 minutes. After incubation, $1.0 \mathrm{~mL}$ of sulphanilic acid reagent was added, mixed well and allowed to stand for 5 minutes for completion of diazotization and $1.0 \mathrm{~mL}$ of N-(1-naphthyl) ethylenediamine dihydrochloride was added, mixed well and allowed to stand for 30 minutes in diffused light. A pink colored chromophore was formed. The absorbance of these solutions was measured at $540 \mathrm{~nm}$ against corresponding blank solutions. Vitamin E was used as a standard.

The inhibition was calculated according to the equation, $I=\left(A_{0}-A_{1}\right) / A_{0} \times 100$

\section{7. Anticancer Activity of $\mathrm{Cu}-\mathrm{ZnO} \mathrm{NPs}$}

The MCF7 and HeLa cells were grown in Eagle's minimum essential medium containing $10 \%$ fetal bovine serum (FBS) while Vero cells were grown in Dulbecco's modified Eagle's medium (DMEM) containing 10\% FBS. $100 \mu \mathrm{L}$ per well of cell suspension were seeded into 96-well 
plates at plating density of 10,000 cells/well and incubated to allow for cell attachment at $37^{\circ} \mathrm{C}, 5 \% \mathrm{CO}_{2}, 95 \%$ air and $100 \%$ relative humidity. After $24 \mathrm{~h}$ the cells were treated with serial concentrations of the test samples $(\mathrm{Cu}-\mathrm{ZnO}$ $\mathrm{NPs}$ ). $\mathrm{Cu}-\mathrm{ZnO} \mathrm{NPs}$ were initially suspended in neat dimethylsulfoxide (DMSO) and an aliquot of the sample solution was diluted to twice the desired final maximum test concentration with serum free medium. Additional four serial dilutions were made to provide a total of five sample concentrations. Triplication was maintained, and the medium without the test sample served as the control. After $24 \mathrm{~h}$, the wells were treated with $20 \mu \mathrm{L}$ MTT [5 mg $\mathrm{mL}^{-1}$ phosphate buffered saline (PBS)] and incubated at 37 ${ }^{\circ} \mathrm{C}$ for $4 \mathrm{~h}$. The medium with MTT was then removed separately and the formed formazan crystals were dissolved in $100 \mathrm{~mL}$ DMSO. The absorbance at $570 \mathrm{~nm}$ was measured using an ELISA plate reader. The graph was plotted between the percentage of cell inhibition and the concentration of the complexes. $\mathrm{IC}_{50}$ values were calculated from the percentage of inhibition. The percentage of cell inhibition was determined using the formula which is given below,

$\%$ inhibition $=[$ mean OD of untreated cells

$($ control)/mean OD of treated cells $($ control) $] \times 100$

\section{Results and Discussion}

\section{1. Ultra Violet-Visible-Diffuse Reflectance Spectroscopy (UV-Vis -DRS)}

Fig. 1 depicts the UV-Vis DRS of $\mathrm{ZnO}$ and $\mathrm{Cu}-\mathrm{ZnO}$ NPs. There are four bands at 213, 255, 358 and $448 \mathrm{~nm}$ for $\mathrm{ZnO}$ nanoparticles. In $\mathrm{Cu}-\mathrm{ZnO} \mathrm{NPs}$ the bands around 200-360 nm remained unaltered.

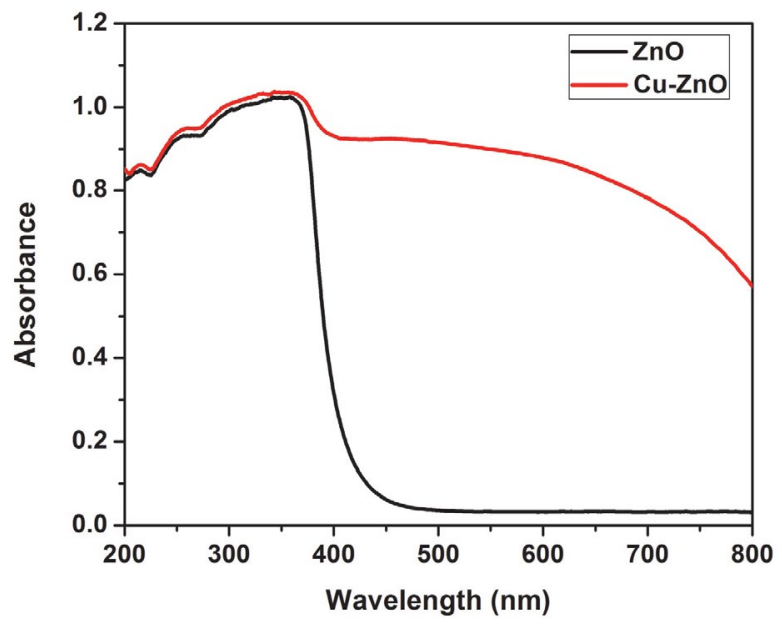

Figure 1. UV-Vis DRS spectra of $\mathrm{ZnO}$ and $\mathrm{Cu}-\mathrm{ZnO}$ NPs

The band which is appeared at $448 \mathrm{~nm}$ is shifted to $464 \mathrm{~nm}$. A slight red shift observed in the case of $\mathrm{Cu}-\mathrm{ZnO}$ is due to the doping of $\mathrm{Cu}$ into the crystal lattice of $\mathrm{Zn}$. The red-shift in absorption peak showed decrease in band gap of $\mathrm{ZnO}$ with $\mathrm{Cu}$ doping. The band gap of $\mathrm{ZnO}$ NPs was decreased from 3.54 to $3.29 \mathrm{eV}$ after doping with copper. Fig. 2 shows the Tauc's plot of $\mathrm{ZnO}(\mathrm{a})$ and $\mathrm{Cu}-\mathrm{ZnO}(\mathrm{b})$. The observed redshift in band gap (Eg) is due to $\mathrm{Cu}$ doping-induced band-edge bending. The change in the band gap energy is attributed to two reasons: First, the sp-d exchange interactions between sp and d orbitals of host and dopant, respectively, lead to negative correction in the conduction band and positive correction in valence band, hence overall band narrowing is observed. ${ }^{31,32}$ Secondly, the electronegativity of $\mathrm{Cu}$ is 1.9 as compared to $\mathrm{ZnO}$ which is 1.6, leading to a chemical affect in the host $\mathrm{ZnO}$ crystal which results in decrease in band gap.
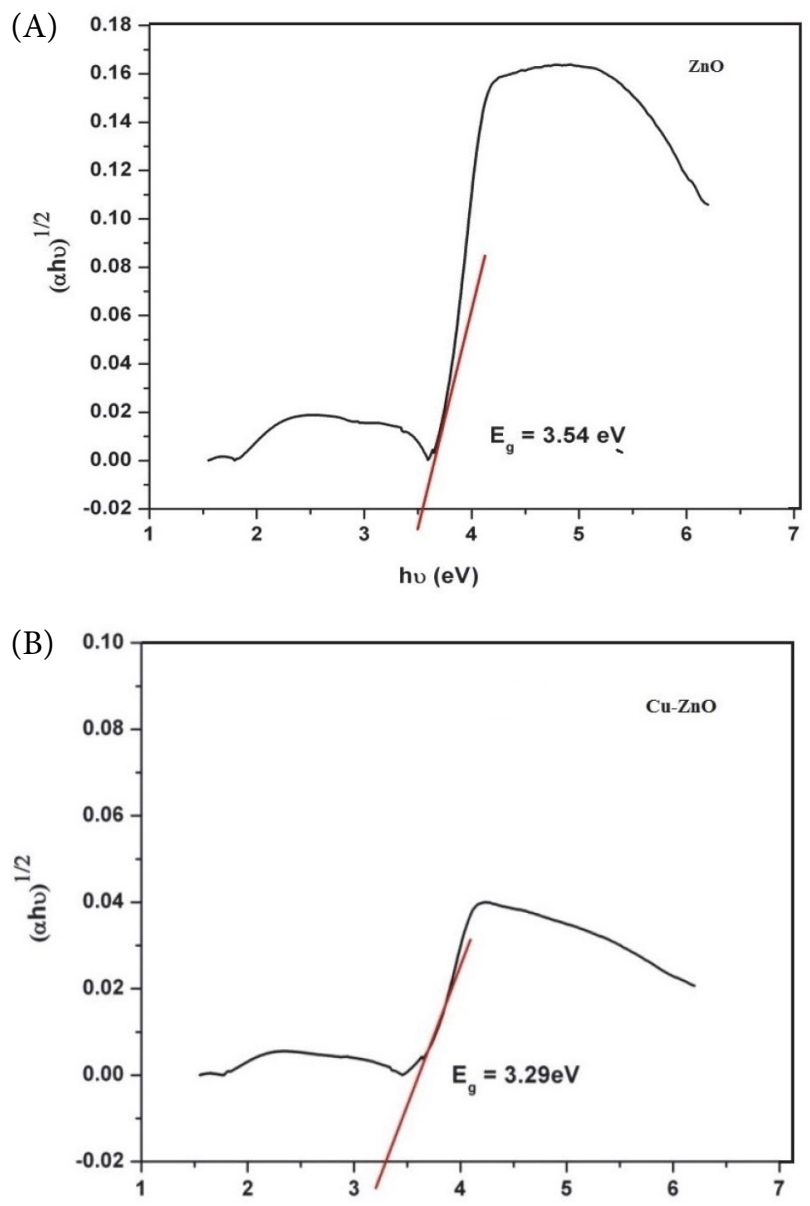

Figure 2. (A) and (B) $\tau$-Plot of $\mathrm{ZnO}$, and $\mathrm{Cu}-\mathrm{ZnO}$ NPs respectively

\section{2. FT-IR Spectral Studies}

The FT-IR spectra of $\mathrm{ZnO}$ and $\mathrm{Cu}-\mathrm{ZnO}$ NPs are represented in Fig 3. The peak observed at 3448 and 1132 $\mathrm{cm}^{-1}$ are attributed to $\mathrm{O}-\mathrm{H}$ stretching vibration of $\mathrm{H}_{2} \mathrm{O}$ in the $\mathrm{Cu}-\mathrm{Zn}-\mathrm{O}$ lattice. The peak at $570 \mathrm{~cm}^{-1}$ is attributed to $\mathrm{Zn}-\mathrm{O}^{33,34}$ whereas in the copper doped $\mathrm{ZnO}$ the corresponding peak is observed at $561 \mathrm{~cm}^{-1} .35$ 


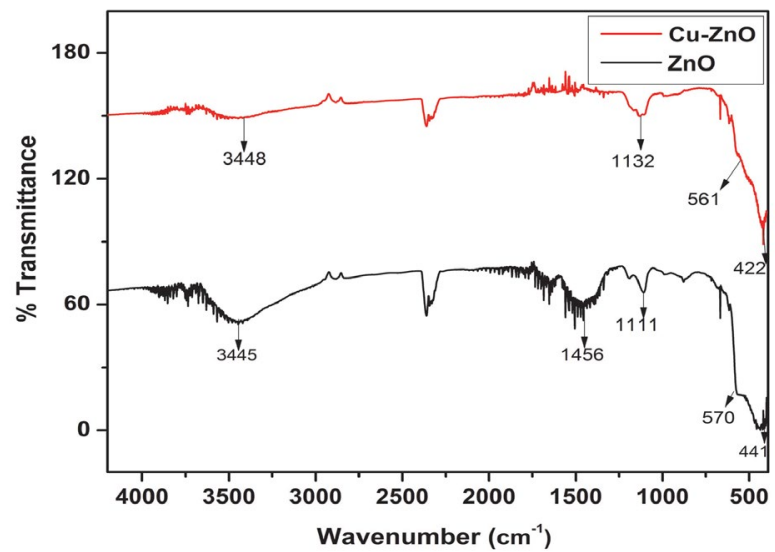

Figure 3. FT-IR data of $\mathrm{ZnO}$ and $\mathrm{Cu}-\mathrm{ZnO} \mathrm{NPs}$

\section{3. X-RAY Diffraction (XRD) Analysis}

The XRD pattern of $\mathrm{ZnO}, \mathrm{Cu}-\mathrm{ZnO}$ is depicted in Fig. (4 \& 5) All the diffraction peaks can be assigned to the $\mathrm{ZnO}$ crystal phase with a hexagonal wurtzite structure (JCPDS-36-1451). The sharp and intensive diffraction peaks indicated that products were well crystallized. The average crystallite size was calculated from Debye-Scherrer formula. ${ }^{36}$ The average crystallite size of $\mathrm{ZnO}$ and $\mathrm{Cu}$ $\mathrm{ZnO}$ are $30 \mathrm{~nm}$ and $27 \mathrm{~nm}$ respectively. From the XRD investigation, the crystal structure of $\mathrm{ZnO}$ and $\mathrm{Cu}-\mathrm{ZnO}$ is wurtzite. The lattice constant for $\mathrm{ZnO}$ and $\mathrm{Cu}-\mathrm{ZnO}$ are $\mathrm{a}=$ $0.3247 \mathrm{~nm}, \mathrm{c}=0.5203 \mathrm{~nm}$ and $\mathrm{a}=0.3249 \mathrm{~nm}, \mathrm{c}=0.5204$ $\mathrm{nm}$ respectively. The very slight shift in peak positions were observed with copper doping in $\mathrm{ZnO}$ indicating that all doped copper occupied the substitution sites. No secondary phases viz., $\mathrm{Cu}_{2} \mathrm{O}, \mathrm{CuO}$, or other metallic $\mathrm{Cu}$ or $\mathrm{Zn}$ phases were observed. It is noteworthy that no copper oxide related peak could be observed in the XRD spectra. One probable reason was that the concentration of doped $\mathrm{Cu}$ was so low that it cannot be detected by XRD. The other reason was that the radius of $\mathrm{Cu}$-ion $(0.073 \mathrm{~nm})$ is similar to that of $\mathrm{Zn}$-ions $(0.074 \mathrm{~nm})$ and the $\mathrm{Cu}$-ions may be incorporated into the lattice of $\mathrm{ZnO}$ structure. ${ }^{37}$ Fig. 5 also shows that $\mathrm{Cu}$-ions doping has almost no influence on the phase structure of $\mathrm{ZnO}$. The intensity of XRD peaks of $\mathrm{Cu}$ $\mathrm{ZnO}$ NPs was decreased in comparison to that of pure $\mathrm{ZnO}$ which indicates a decrease in crystallinity of $\mathrm{ZnO}$ with $\mathrm{Cu}$ doping. The decrease in crystallite size implies that doping with $\mathrm{Cu}$ restrains increase of grain size and refines the crystal size.

\section{4. Scanning Electron Microscope (SEM) Analysis}

The morphology of $\mathrm{ZnO}, \mathrm{Cu}-\mathrm{ZnO}$ NPs was elucidated by SEM analysis. SEM micrographs of $\mathrm{ZnO}$, and $\mathrm{Cu}-$ $\mathrm{ZnO}$ are depicted in Fig.6 (A-D). It was clearly observed that the particles were spherical in shape and well dispersed.

$\mathrm{ZnO}$ structure was observed like a stack of vertically aligned thin nanosheets whereas $\mathrm{Cu}-\mathrm{ZnO}$ possessed rods and grain like structures. The average grain size of all the samples is in the range of $40-60 \mathrm{~nm}$. Cu doping strongly influences the grain size and morphology of $\mathrm{ZnO}$ nano-

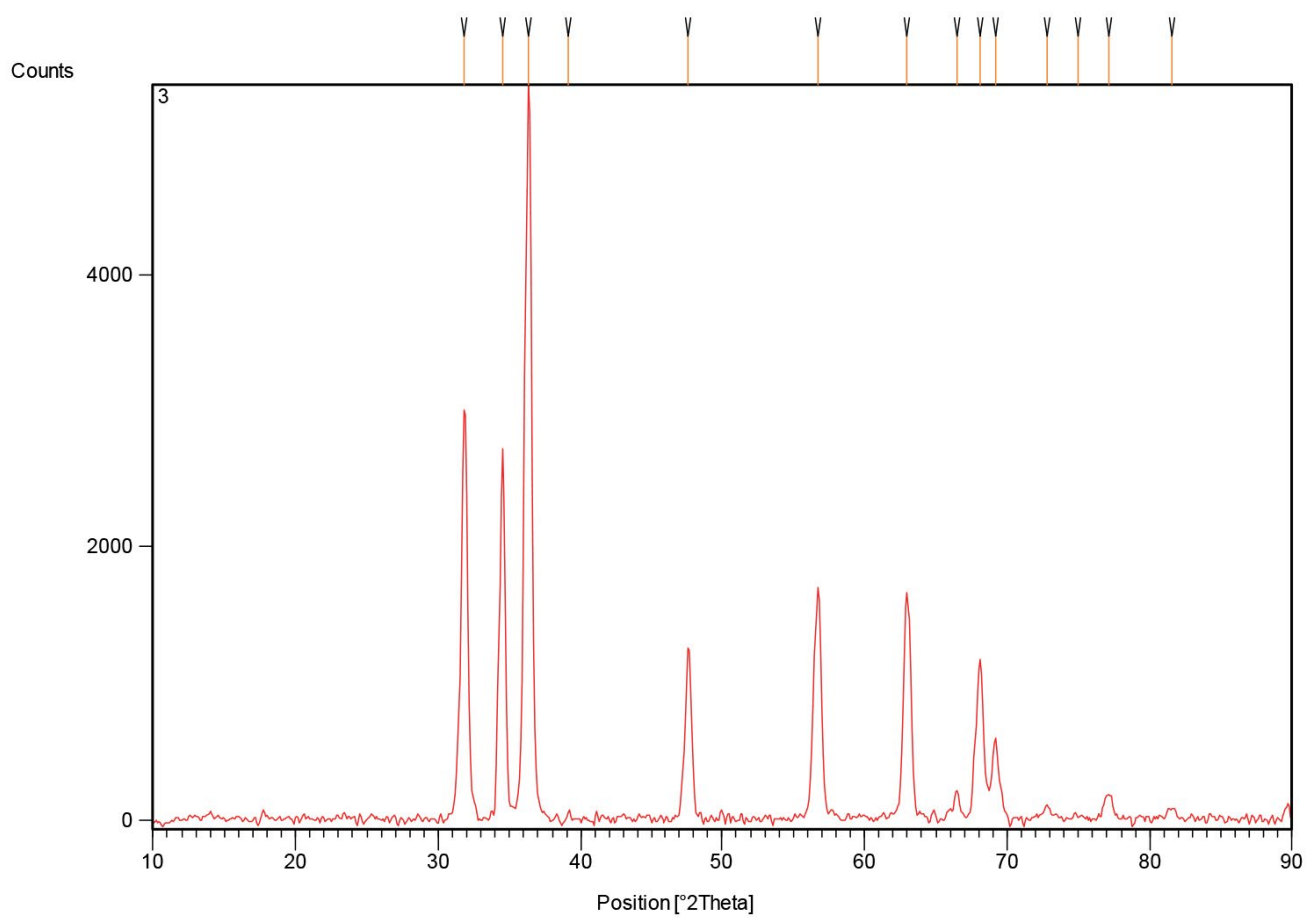

Figure 4. XRD pattern of $\mathrm{ZnO} N P s$ 


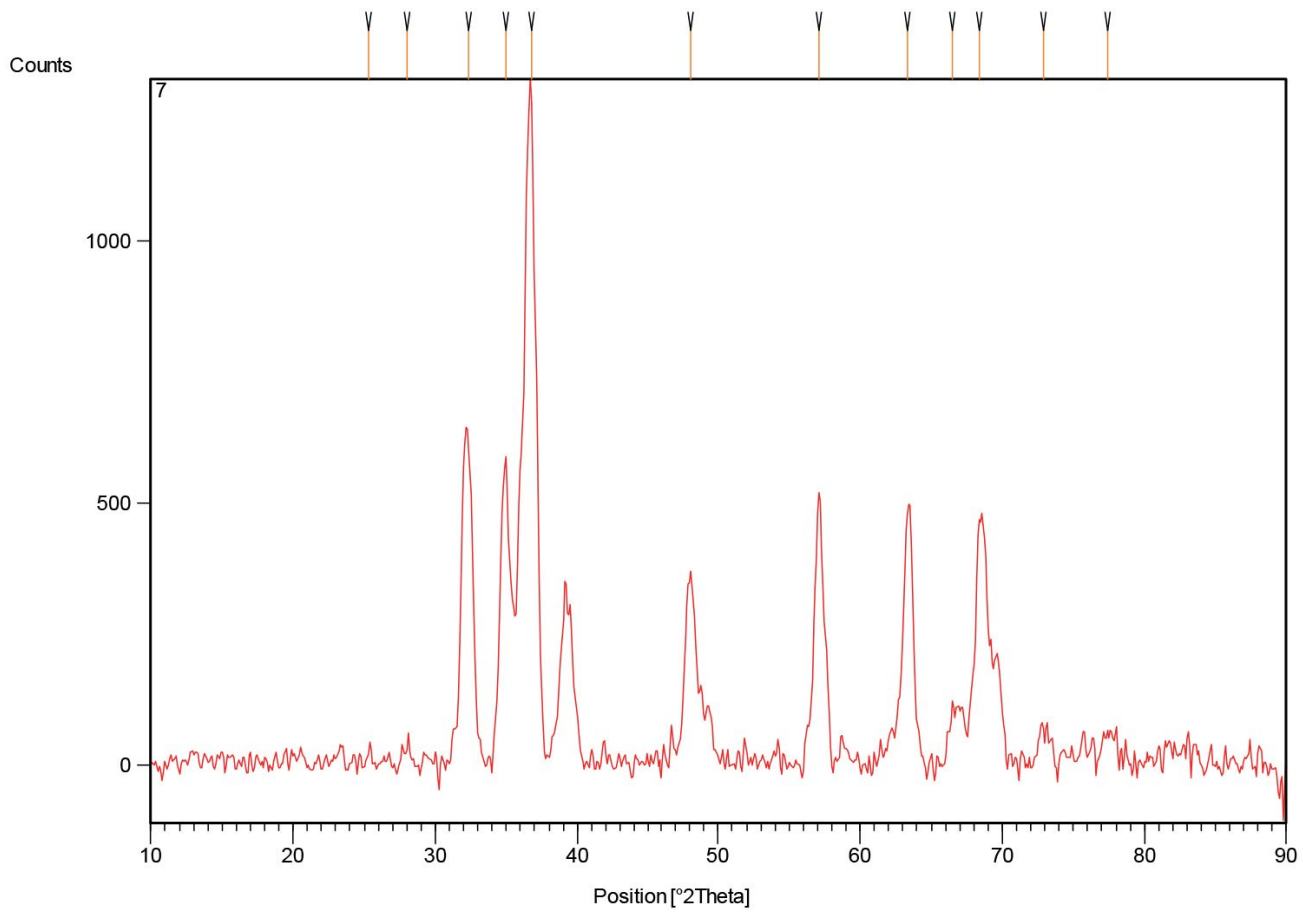

Figure 5. XRD pattern of $\mathrm{Cu}-\mathrm{ZnO} \mathrm{NPs}$
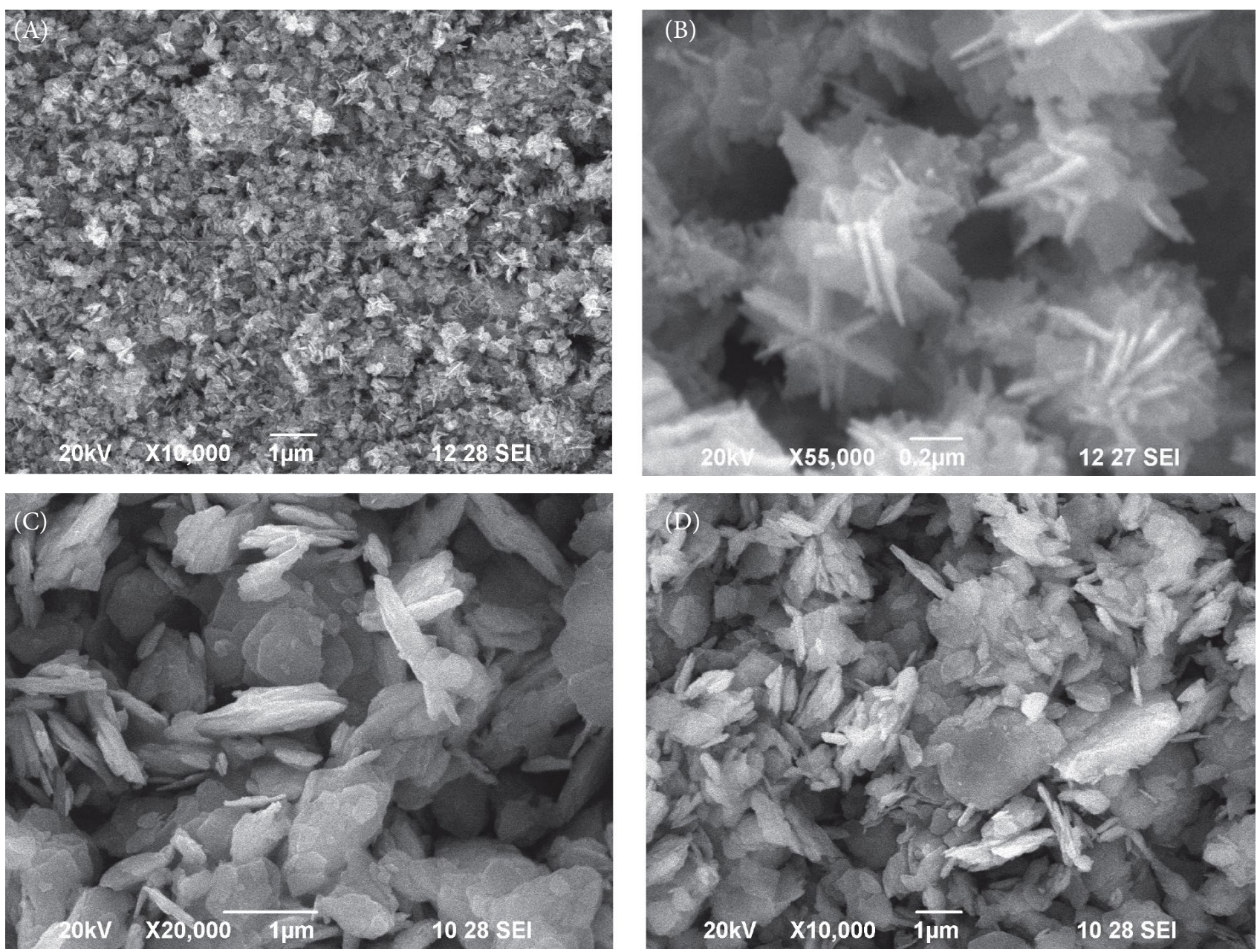

Figure 6. SEM images of $\mathrm{ZnO}(\mathrm{A})$ and $\mathrm{Cu}-\mathrm{ZnO}(\mathrm{B}-\mathrm{D}) \mathrm{NPs}$ at various magnification 
particles. The average particle size was found to decrease with the increase in $\mathrm{Cu}$ doping into the $\mathrm{ZnO}$ matrix. The decrease in the particle size was mostly ascribed to the formation of $\mathrm{Cu}-\mathrm{O}-\mathrm{Zn}$ on the surface of the doped nanoparticles, which prevents the growth of crystal grains and assists separation of particles. ${ }^{38}$

\section{5. Energy-Dispersive X-ray Analysis (EDAX)}

EDAX was carried out to analyze the chemical composition and formation of un-doped $\mathrm{ZnO}$ and $\mathrm{Cu}-\mathrm{ZnO}$ NPs. EDAX was used to confirm the presence of cationic metal ion $\left(\mathrm{Cu}^{2+}\right)$ dopant in $\mathrm{ZnO}$. Fig. 7 shows the EDAX spectrum of $\mathrm{ZnO}$ (a) and $\mathrm{Cu}-\mathrm{ZnO}$ (b). In addition, the EDAX spectra confirmed the presence of chemical constituents $(\mathrm{Zn}=72.96 \%$ and $\mathrm{O}=27.04 \%$ in un-doped $\mathrm{ZnO} N$ Ps; $\mathrm{Cu}=3.21 \%, \mathrm{Zn}=52.71 \%$ and $\mathrm{O}=39.12 \%$ in $\mathrm{Cu}-\mathrm{ZnO} \mathrm{NPs}$, it was also found that sample $\mathrm{Cu}-\mathrm{ZnO}$ was composed only by $\mathrm{Zn}, \mathrm{Cu}$ and $\mathrm{O}$ without any other impurities. The EDAX peak positions were consistent with $\mathrm{ZnO}$, and the sharp peaks of EDAX indicated that the synthesized NPs had crys- talline structures. ${ }^{39,40}$ The strong intensity and narrow width of $\mathrm{ZnO}$ diffraction peaks indicate that the resultant products were highly crystalline in nature. These findings were in close agreement with previous reports ${ }^{41}$ but with slight difference due to variations in chemical composition.

\section{6. Antimicrobial Activity}

Comparative analysis of the antimicrobial efficacy of $\mathrm{ZnO}$ and $\mathrm{Cu}-\mathrm{ZnO}$ NPs was carried out using well diffusion method and the results are tabulated in Tables 1 and 2. The antibacterial activity of $\mathrm{ZnO}$ and $\mathrm{Cu}-\mathrm{ZnO} N P$ s was studied against three bacterial strains such as $1 \mathrm{~B}, 2 \mathrm{~B}, 3 \mathrm{~B}$ and three fungal strains $1 F, 2 \mathrm{~F}$ and $3 \mathrm{~F}$. The zone of inhibition $(\mathrm{mm})$ was evaluated for three concentrations such as $50 \mu \mathrm{L}, 75 \mu \mathrm{L}$ and $100 \mu \mathrm{L}$. It was clearly indicated that the percentage enhancement of the activity for $1 \mathrm{~B}$ was $60 \%$ in the case of $50 \mu \mathrm{L}$. But in the case of $2 \mathrm{~B}$ and $3 \mathrm{~B}$ were $70.5 \%$ and $75 \%$ respectively. The results showed that the $\mathrm{Cu}-\mathrm{ZnO}$ showed good inhibitory action against $3 \mathrm{~B}$. In the second case $(75 \mu \mathrm{L})$ the percentage of enhancement of $1 \mathrm{~B}, 2 \mathrm{~B}$ and $3 \mathrm{~B}$ were $62.5 \%, 72.2 \%$ and $80.9 \%$ respectively.

Table 1. Antibacterial activity of $\mathrm{Cu}-\mathrm{ZnO}$ NPs

\begin{tabular}{|c|c|c|c|c|c|c|c|c|c|}
\hline \multirow[t]{2}{*}{$\begin{array}{l}\text { Name of } \\
\text { the Sample }\end{array}$} & \multicolumn{3}{|c|}{ E.coli } & \multicolumn{3}{|c|}{$\begin{array}{l}\text { Zone of inhibition in } \mathrm{mm} \\
\text { Pseudomonas aerugenousa }\end{array}$} & \multicolumn{3}{|c|}{ Staphylococcus aeureus } \\
\hline & $50 \mu \mathrm{L}$ & $75 \mu \mathrm{L}$ & $100 \mu \mathrm{L}$ & $50 \mu \mathrm{L}$ & $75 \mu \mathrm{L}$ & $100 \mu \mathrm{L}$ & $50 \mu \mathrm{L}$ & $75 \mu \mathrm{L}$ & $100 \mu \mathrm{L}$ \\
\hline $\mathrm{ZnO}$ & $12 \pm 0.5$ & $13 \pm 0.8$ & $14 \pm 0.2$ & $11 \pm 0.4$ & $12 \pm 0.9$ & $13 \pm 0.7$ & $10 \pm 0.8$ & $12 \pm 0.1$ & $13 \pm 0.6$ \\
\hline $\mathrm{Cu}-\mathrm{ZnO}$ & $16 \pm 0.9$ & $17 \pm 0.4$ & $18 \pm 0.1$ & $16 \pm 0.4$ & $17 \pm 0.1$ & $17 \pm 0.9$ & $15 \pm 0.3$ & $16 \pm 0.5$ & $17 \pm 0.2$ \\
\hline Amikacin & $18 \pm 0.2$ & $20 \pm 0.45$ & $22 \pm 0.3$ & $17 \pm 0.8$ & $19 \pm 0.2$ & $21 \pm 0.5$ & $16 \pm 0.9$ & $18 \pm 0.8$ & $20 \pm 1.2$ \\
\hline
\end{tabular}
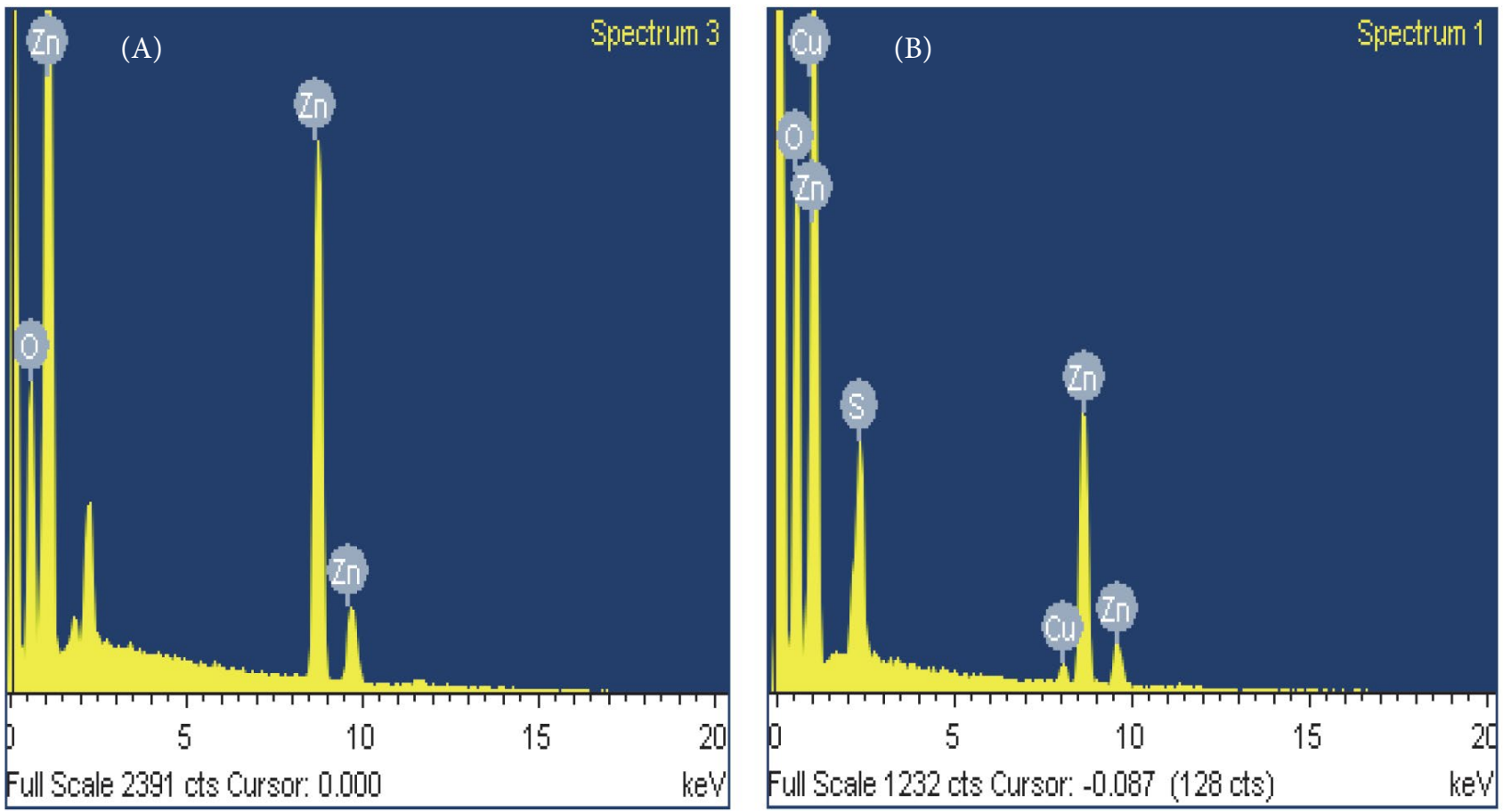

Figure 7. EDAX spectra of (A) $\mathrm{ZnO}$ and (B) $\mathrm{Cu}-\mathrm{ZnO} \mathrm{NPs}$ 
Table 2. Antifungal activity of $\mathrm{Cu}-\mathrm{ZnO} \mathrm{NPs}$

\begin{tabular}{|c|c|c|c|c|c|c|c|c|c|}
\hline \multirow[t]{2}{*}{$\begin{array}{l}\text { Name of } \\
\text { the Sample }\end{array}$} & \multicolumn{3}{|c|}{ Aspergillus flavus } & \multicolumn{3}{|c|}{$\begin{array}{l}\text { Zone of inhibition in } \mathrm{mm} \\
\text { Candida albicans }\end{array}$} & \multicolumn{3}{|c|}{ Fusarium sp } \\
\hline & $50 \mu \mathrm{L}$ & $75 \mu \mathrm{L}$ & $100 \mu \mathrm{L}$ & $50 \mu \mathrm{L}$ & $75 \mu \mathrm{L}$ & $100 \mu \mathrm{L}$ & $50 \mu \mathrm{L}$ & $75 \mu \mathrm{L}$ & $100 \mu \mathrm{L}$ \\
\hline $\mathrm{ZnO}$ & $13 \pm 0.1$ & $15 \pm 0.4$ & $17 \pm 0.56$ & $12 \pm 0.3$ & $14 \pm 0.2$ & $15 \pm 1.0$ & $12 \pm 0.8$ & $14 \pm 1.0$ & $17 \pm 0.1$ \\
\hline $\mathrm{Cu}-\mathrm{ZnO}$ & $17 \pm 0.4$ & $18 \pm 0.7$ & $20 \pm 1.0$ & $16 \pm 0.8$ & $17 \pm 0.9$ & $19 \pm 1.0$ & $17 \pm 0.1$ & $18 \pm 0.3$ & $19 \pm 0.9$ \\
\hline Ketoconazole & $20 \pm 0.6$ & $22 \pm 0.3$ & $24 \pm 0.4$ & $19 \pm 0.6$ & $21 \pm 0.3$ & $23 \pm 0.1$ & $20 \pm 0.2$ & $22 \pm 0.05$ & $24 \pm 0.3$ \\
\hline
\end{tabular}

It was revealed that the zone of inhibition (\%) was increased with concentration. If concentration increased to $100 \mu \mathrm{L}$, the percentage of enhancement of $1 \mathrm{~B}, 2 \mathrm{~B}$ and $3 \mathrm{~B}$ were $64.7 \%, 73.6 \%$ and $86.3 \%$ respectively.

Similarly, the antifungal activity of $\mathrm{ZnO}$ and $\mathrm{Cu}-\mathrm{ZnO}$ has been investigated systematically. Additionally, the zone of inhibition ( $\mathrm{mm}$ ) has been evaluated for three kinds of fungal species such as $1 \mathrm{~F}, 2 \mathrm{~F}$ and $3 \mathrm{~F}$. In this connection, three concentrations such as $50 \mu \mathrm{L}, 75 \mu \mathrm{L}$ and $100 \mu \mathrm{L}$ were taken for the analysis. The percentage of enhancement was also calculated. From the results, the percentage of enhancement for $1 \mathrm{~F}, 2 \mathrm{~F}$ and $3 \mathrm{~F}$ were $76.4 \% ; 7 \%$ and $73.3 \%$ respectively. On increasing the concentration to $75 \mu \mathrm{L}$ and $100 \mu \mathrm{L}$, the zone of inhibition increases. However, the percentage of enhancement from $\mathrm{ZnO}$ to $\mathrm{Cu}-\mathrm{ZnO}$ was $83.3 \%$ $(1 \mathrm{~F}), 82.3 \%(2 \mathrm{~F})$ and $75 \%(3 \mathrm{~F})$ respectively. The results indicated that the percentage of enhancement was observed
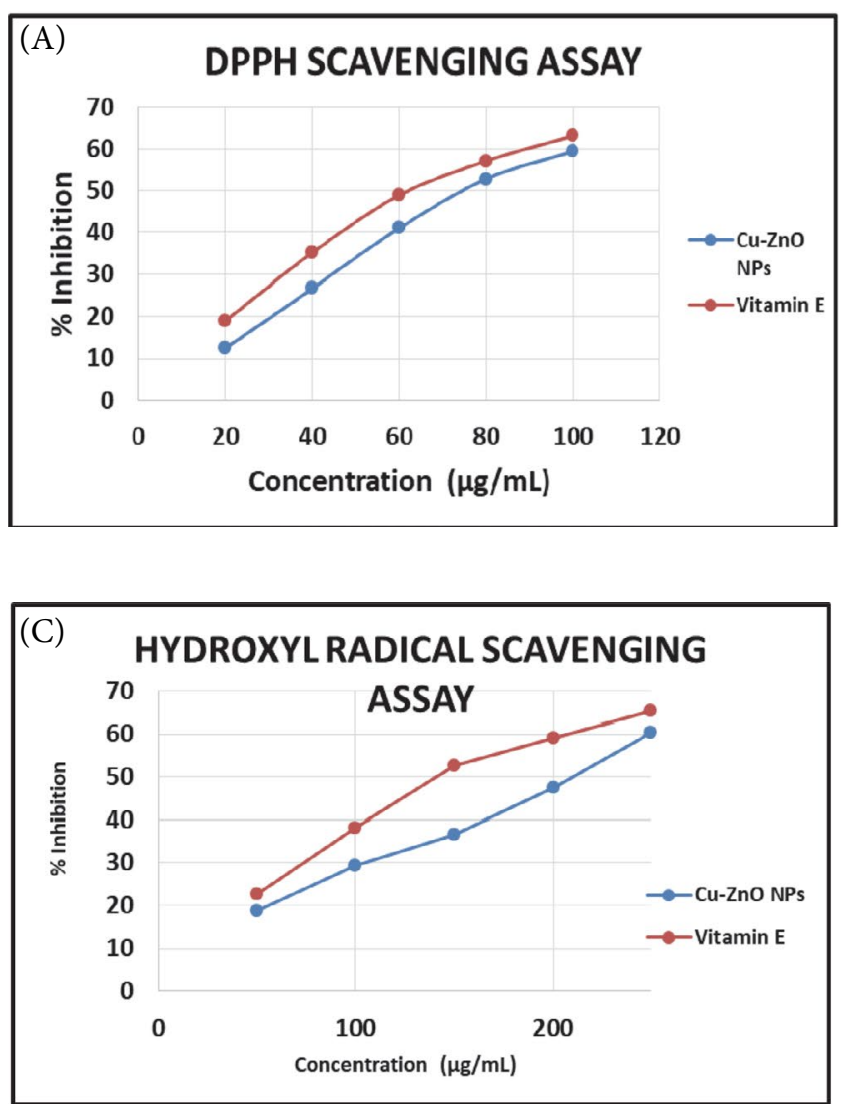

maximum for $\mathrm{Cu}-\mathrm{ZnO}(100 \mu \mathrm{L}$ concentration $)$ against $1 \mathrm{~F}$.

The results revealed that both $\mathrm{ZnO}$ and $\mathrm{Cu}-\mathrm{ZnO}$ NPs were effective antibacterial agents on gram-positive as well as on gram-negative bacteria. However, percentage reduction in bacterial growth was found to be significantly higher using $\mathrm{Cu}-\mathrm{ZnO}$ NPs compared to that of the $\mathrm{ZnO}$ NPs. Thus, the antibacterial effect of $\mathrm{ZnO}$ and $\mathrm{Cu}-\mathrm{ZnO}$ was more pronounced for gram-positive bacteria as compared to gram-negative bacteria, which was in good agreement with the earlier studies. ${ }^{31,42-44}$ This was explained on the basis of differences in (i) cell membrane structure, (ii) physiology and metabolic activities of the cell, and (iii) degree of contact of gram-positive and gram-negative bacteria. ${ }^{45}$ The antibacterial activity of pure and iron-doped $\mathrm{ZnO}$ nanoparticles showed that they were more resistant to gram-negative bacteria than gram-positive bacteria. The results were in good agreement with our results. ${ }^{46}$
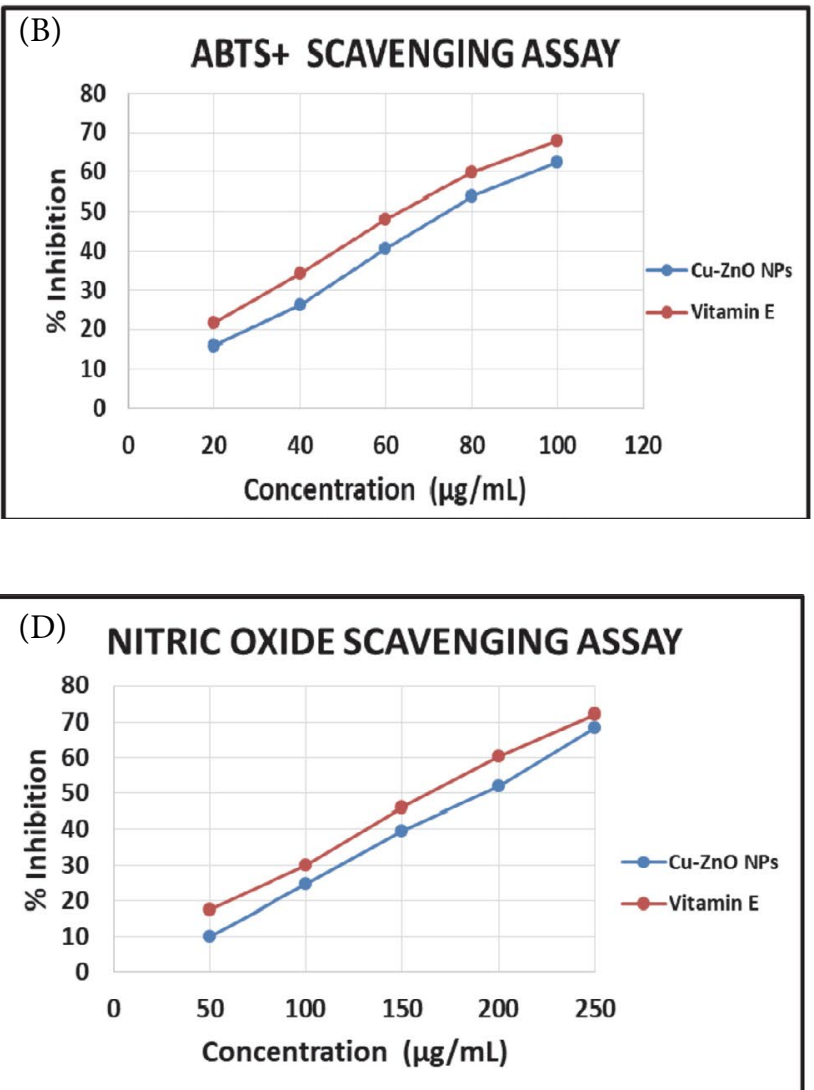

Figure 8. (A) DPPH, (B) $\mathrm{ABTS}^{+},(\mathrm{C}) \cdot \mathrm{OH},(\mathrm{D}) \mathrm{NO} \cdot$ radical scavenging activities of $\mathrm{Cu}-\mathrm{ZnO}$ NPs and standard at various concentrations. 


\section{7. Antioxidant Activity}

The antioxidant activity of $\mathrm{Cu}-\mathrm{ZnO}$ NPs were evaluated in a series of in vitro assays involving DPPH radicals, ABTS cationic radicals, hydroxyl radicals, nitric oxide scavenging assay in a dose dependent manner. The antioxidant activities of the $\mathrm{Cu}-\mathrm{ZnO}$ NPs along with the standard at various concentrations have been shown in Fig.8 respectively. The $\mathrm{IC}_{50}$ values of $\mathrm{Cu}-\mathrm{ZnO}$ NPs in relevance to $\mathrm{DPPH}, \mathrm{ABTS}^{+}, \cdot \mathrm{OH}, \mathrm{NO} \cdot$ assays were $76.29,74.07$, 205.96 and $180.89 \mu \mathrm{g} / \mathrm{mL}$ respectively (Table 3 ). From the results, the minimum and maximum percentage of inhibition for $\mathrm{Cu}-\mathrm{ZnO}$ NPs against DPPH radicals for the concentration of $20 \mu \mathrm{g} / \mathrm{mL}$ and $100 \mu \mathrm{g} / \mathrm{mL}$ were $12.54 \pm 0.28$ and $59.45 \pm 0.16$ respectively. $\mathrm{ABTS}^{+}$scavenging assay was also carried out to evaluate the free radical scavenging activity of the synthesized $\mathrm{Cu}-\mathrm{ZnO}$ NPs. The minimum and maximum percentages of inhibition for $20 \mu \mathrm{g} / \mathrm{mL}$ and 100 $\mu \mathrm{g} / \mathrm{mL}$ concentrations were $15.75 \pm 0.26$ and $62.48 \pm 0.18$ respectively. In the case of hydroxyl radicals scavenging assay, the free radical scavenging activity was investigated using various concentrations such as $50 \mu \mathrm{g} / \mathrm{mL}, 100 \mu \mathrm{g} /$ $\mathrm{mL}, 150 \mu \mathrm{g} / \mathrm{mL}, 200 \mu \mathrm{g} / \mathrm{mL}$ and $250 \mu \mathrm{g} / \mathrm{mL}$. The scavenging activity was increased with concentration as expected. The minimum and maximum percentage of inhibition at the concentrations of $50 \mu \mathrm{g} / \mathrm{mL}$ and $250 \mu \mathrm{g} / \mathrm{mL}$ were 18.61 \pm 0.23 and $60.45 \pm 0.55$ respectively. Nitric oxide scavenging assay was also carried out for evaluation of free radical scavenging activity of $\mathrm{Cu}-\mathrm{ZnO}$ NPs. The minimum and maximum percentage of inhibition at the concentration $50 \mu \mathrm{g} / \mathrm{mL}$ and $250 \mu \mathrm{g} / \mathrm{mL}$ were $10.15 \pm 0.61$ and $68.36 \pm$ 0.94 respectively. The results indicated that the synthesized $\mathrm{Cu}-\mathrm{ZnO}$ NPs exhibited appreciable antioxidant activity. The results were compared with the standard Vitamin E. The comparison clearly indicated that the $\mathrm{Cu}-\mathrm{ZnO}$ NPs exhibited comparable activity with that of the standard. The results revealed that a concentration dependent activity was observed.

Table 3. $\mathrm{IC}_{50}$ values (in $\mu \mathrm{g} / \mathrm{mL}$ ) calculated from various radical scavenging assays of $\mathrm{Cu}-\mathrm{ZnO} \mathrm{NPs}$ and standard vitamin $\mathrm{E}$

\begin{tabular}{lcccc}
\hline Compound & DPPH & ABTS & •OH & NO. \\
\hline Cu-ZnO & 76.29 & 74.07 & 205.96 & 180.89 \\
Vitamin E & 63.32 & 63.14 & 147.88 & 158.13 \\
\hline
\end{tabular}

\section{8. Anticancer Activity}

The in vitro cytotoxic activity of the compound was determined against human breast (MCF7), human cervical (HeLa) cancer and Vero cell lines using MTT assay. Figure 9 showed the cytotoxicity of the ZnO NPs after $48 \mathrm{~h}$ incubation on MCF7, HeLa and Vero cell lines respectively. The results were analyzed by means of cell inhibition expressed as $\mathrm{IC}_{50}$ values. $\mathrm{Cu}-\mathrm{ZnO}$ NPs showed only mod- erate activity with $\mathrm{IC}_{50}$ value of 219.56 and $137.27 \mu \mathrm{g} / \mathrm{mL}$ against MCF7 and HeLa cell lines respectively. Fortunately, $\mathrm{Cu}-\mathrm{ZnO} \mathrm{NPs}$ are less toxic towards the normal cell line which was evident from its high $\mathrm{IC}_{50}$ value $(>300 \mu \mathrm{g} / \mathrm{mL})$. This showed that our $\mathrm{Cu}-\mathrm{ZnO}$ NPs are particularly toxic towards cancer cell lines.

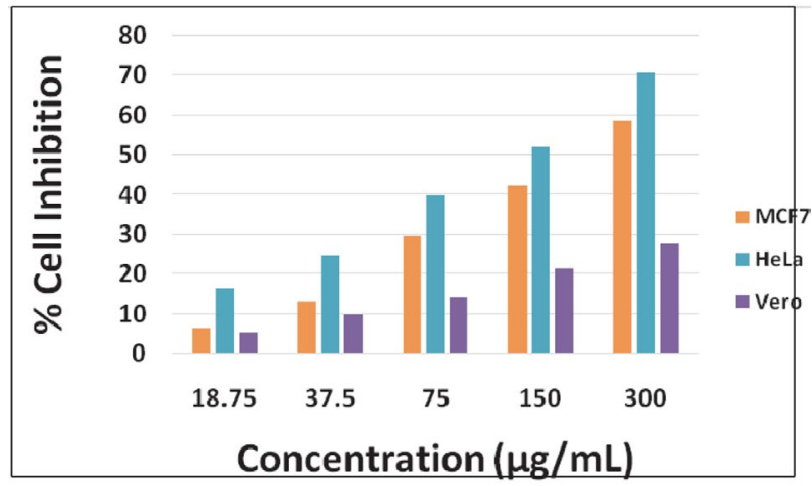

Figure 9. Cytotoxicity of $\mathrm{Cu}-\mathrm{ZnO}$ NPs in MCF7, HeLa and Vero cell lines

\section{Conclusions}

In the present work, we have accomplished the synthesis of $\mathrm{ZnO}$ and $\mathrm{Cu}-\mathrm{ZnO}$ nanoparticles. The antibacterial and antioxidant activity of the synthesized $\mathrm{ZnO}$ and $\mathrm{Cu}-\mathrm{ZnO} \mathrm{NPs}$ were investigated. The anticancer activity of $\mathrm{Cu}-\mathrm{ZnO}$ NPs was also evaluated. $\mathrm{Cu}-\mathrm{ZnO}$ NPs showed superior antibacterial action against grampositive as well as gram-negative bacteria. In addition, doped $\mathrm{ZnO}$ NPs had shown appreciable antioxidant activity against $\mathrm{DPPH}, \mathrm{ABTS}^{+}, \cdot \mathrm{OH}$ and $\mathrm{NO} \cdot$ assays. The UV-Visible results revealed that band gap undergoes a red-shift in doped $\mathrm{ZnO}$ nanorods as compared to pure $\mathrm{ZnO}$. We infer that strong bonding of $\mathrm{Cu}$ in the host lattice of $\mathrm{ZnO}$ was responsible for the significant reduction of $\mathrm{ZnO}$ nanoparticle dissolution. $\mathrm{Cu}-\mathrm{ZnO}$ NPs exhibited moderate anticancer activity against the tested cell lines. One of the important findings of this study was that $\mathrm{Cu}$-doping unaltered the benign nature of $\mathrm{ZnO}$ nanoparticles towards the normal (Vero) cells. Overall, our data suggested a novel approach through which the inherent selective cytotoxicity of $\mathrm{ZnO}$ NPs against human breast cancer cells (MCF7) and human cervical carcinoma (HeLa) can be improved by doping of $\mathrm{Cu}^{2+}$ ion. Further research on anticancer activity of $\mathrm{Cu}-\mathrm{ZnO}$ NPs in different types of cancer cells is warranted.

\section{Acknowledgements}

Author thanks Dr. R. Karvembu, Department of Chemistry, National Institute of Technology, Tiruchirappalli for providing the lab facility. 


\section{References}

1. G. Bisht, S. Rayamajhi, Nanobiomedicine. 2016, 3, 1-11. DOI: $10.5772 / 63437$

2. K. S. Smalley, M. Herlyn, Mini Rev Med Chem. 2006, 6, 387393. DOI:10.2174/138955706776361402

3. R. Langer, Nature. 1998, 392, 5-10. DOI:10.1038/32020

4. R. Gowda, N. R. Jones, J. Nanomed Nanotechnol. 2013, 4, 184-219.

5. I. Baskaran, T. S. N. Sankara Narayanan, A. Stephen, Mater. Lett. 2006, 60,1990-1995. DOI:10.1016/j.matlet.2005.12.065

6. M. F. Serag, N. Kaji, S. Habuchi, A. Biancod, Y. Baba, RSC Adv. 2013, 3, 4856-4862. DOI:10.1039/c2ra22766e

7. S. Poyraz, I. Cerkez, T. S. Huang, Z. Liu, L. Kang, J. Luo, X. Zhang, ACS Appl. Mater. Interfaces. 2014, 6, 20025-20034. DOI:10.1021/am505571m

8. R. Wang, P. S. Billone, W. M. Mullett, J. Nanomater. 2013, 2013, 1-12. DOI:10.1155/2013/629681

9. S. E. McNeil, Nanomed. Nanobiotechnol. 2009, 1, 264-271. DOI:10.1002/wnan.6

10. M. J. Akhtar, H. A. Alhadlaq, A. Alshamsan, M. A. Majeed Khan, M. Ahamed, Scientific Reports. 2015, 5, 13876.

DOI:10.1038/srep13876

11. J. W. Rasmussen, E. Martinez, P. Louka, D. G. Wingett, Expert Opin. Drug Deliv. 2010, 9, 1063-1077.

DOI: $10.1517 / 17425247.2010 .502560$

12. M. Premanathan, K. Karthikeyan, K. Jeyasubramanian, G. Manivannan, Nanomed Nanobiotechnol. 2011, 7, 184-192. DOI:10.1016/j.nano.2010.10.001

13. C. Hanley, J. Layne, A. Punnoose, K. M. Reddy, I. Coombs, A. Coombs, K. Feris, D. Wingett, Nanotechnology. 2008, 19, 295103-295113. DOI:10.1088/0957-4484/19/29/295103

14. A. B. Moghaddam, M. Moniri, S. Azizi, R. A. Rahim, A. B. Ariff, M. Navaderi and R. Mohamad, Genes. 2017, 8, 281-295. DOI:10.3390/genes8100281

15. S. A. Khan, F. Noreen, S. Kanwal, G. Hussain, Dig J Nanomater Biostruct. 2017, 12, 877-890.

16. K. Kalantar, K. Kabir, F. Gharibi, S. Hatami, A. Maleki, J Med Bacteriol. 2013, 2, 20-26.

17. R. Chauhan, A. Kumar, R. P. Chaudhary, J Chem Pharm Res. 2010, 2, 178-183.

18. G. Glaspell, P. Dutta, A. Manivanna, J. Clust. Sci. 2005, 16, 523-536. DOI:10.1007/s10876-005-0024-y

19. A. N. Malika, A. R. Reddy, K. S. Babu, K.V. Reddy, Ceram. Int. 2014, 40, 12171-12177.

20. S. Deka, P. A. Joy, Solid State Commun. 2007, 142, 190-194. DOI:10.1016/j.ssc.2007.02.017

21. R. Saleh, N. F. Djaja, Spectrochim Acta A Mol Biomol Spectrosc. 2014, 130, 581-590. DOI:10.1016/j.saa.2014.03.089

22. O. G. Jayakumar, H. G. Salunke, R. M. Kadam, M. Mohapartra, G. Yaswant, S. K. Kulshreshtha, Nanotechnology. 2006, 17, 1278-1285. DOI:10.1088/0957-4484/17/5/020

23. M. E. Abrishami, A. Kompany, S. M. Hosseini, N. G. Bardar, J Solgel Sci Technol. 2012, 62, 153-159.

DOI:10.1007/s10971-012-2701-2

24. S. Kim, J. H. Jun, K. Chao, J. Yun, K. S. Suh, T. Y. Kim, Organic Electron. 2008, 9, 445-451.
DOI:10.1016/j.orgel.2008.02.001

25. Y. Lu, J. Zhong, S. Muthukumar, Y. Chen, H. M. Ng, W. Jiang, E. L. Garfunkel, Appl Phys. Lett. 2003, 83, 3401-3403. DOI:10.1063/1.1621729

26. D. Meng, X. Yu, C. Liu, X. He, Y. Wang, J. Xie, Material Letter. 2012, 86, 112-114. DOI:10.1016/j.matlet.2012.07.040

27. S. A. Khan, F. Noreen, S. Kanwal, A. Iqbal, G. Hussain, Mater. Sci. Eng. C. 2018, 82, 46-59. DOI:10.1016/j.msec.2017.08.071

28. M. S. Blois, Nature. 1958, 29, 1199-1200.

DOI: $10.1038 / 1811199 \mathrm{a} 0$

29. T. Nash, Bihem. J. 1953, 55, 416-421.

DOI:10.1042/bj0550416

30. D. J. Stueher, M. A. Marletta, J. Immunol. 1987, 139, 518-525.

31. T. Bhuyan, M. Khanuja, R. Sharma, S. Patel, M. R. Reddy, S. Anand, A. Varma, J. Nanopart Res. 2015, 17, 1-11.

DOI:10.1007/s11051-015-3093-3

32. K. S. Ahn, T. Deutsch, Y. Yan, C. S. Jiang, C. L. Perkins, J. Turner, M. A. I. Jassim, J Appl Phys. 2007, 102, 23517-23522.

33. S. Maensiri, P. Laokul, V. Promarak, J. Cryst. Growth. 2006, 289, 102-106. DOI:10.1016/j.jcrysgro.2005.10.145

34. S. Suwanboon, Sci. Asia, 2008, 34, 31-34. DOI:10.2306/scienceasia1513-1874.2008.34.031

35. Y. C. Zhang, J. Y Jang, G. L. Wang, M. Zhang, X. Y. Hu, J. Cryst. Growth. 2006, 294, 278-282.

DOI:10.1016/j.jcrysgro.2006.06.038

36. C. L. Xua, D. H. Qina, H. Li, Y. Guo, T. Xu, H. L. Li, Mater. Lett. 2004, 58, 3976-3979. DOI:10.1016/j.matlet.2004.08.026

37. M. Fua, Y. Li, S. Wu, P. Lu, J. Liu, F. Donga, Appl Surf Sci. 2011, 258, 1587-1598. DOI:10.1016/j.apsusc.2011.10.003

38. A. Samavati, A. F. Ismail, H. Nur, Z. Othaman, M. K. Mustafa, Chin. Phys. B. 2016, 25, 077803-077809.

DOI:10.1088/1674-1056/25/7/077803

39. S. A. Khan, F. Noreen, S. Kanwal, A. Iqbal, G. Hussain, Mater. Sci. Eng. C. 2017, 82, 46-59.

DOI:10.1016/j.msec.2017.08.071

40. S. Y. Pung, C. S. Ong, K. M. Isha, M. H. Othman, Sains Malays. 2014, 43, 273-281.

41. H. R. Ghaffarian, M. Saiedi, M. A. Sayyadnejad, A. M. Rashidi, Iran. J. Chem. Chem. Eng. 2011, 30, 1-6.

42. M. Premanathan, K. Karthikeyan, K. Jeyasubramanian, G. Manivannan, Nanomedicine. 2011, 7, 184-192.

DOI:10.1016/j.nano.2010.10.001

43. K. R. Raghupathi, R. T. Koodali, A. C. Manna, Langmuir. 2011, 27, 4020-4028. DOI:10.1021/la104825u

44. T. Bhuyan, K. Mishra, M. Khanuja, R. Prasad, A.Varma, Mater Sci Semicond Process. 2015, 32, 55-61.

DOI:10.1016/j.mssp.2014.12.053

45. W. K. Jung, H. C. Koo, K. W. Kim, S. Shin, S. H. Kim, Y. H. Park, Appl Environ Microbiol. 2008, 74, 2171-2178.

DOI:10.1128/AEM.02001-07

46. M. Li, S. Pokhrel, X. Jin, L. Madler, R. Damoiseaux, E. M. V. Hoek, Environ Sci Technol. 2011, 45, 755-761.

DOI:10.1021/es102266g 


\section{Povzetek}

V prispevku preučujemo, kako dopiran baker $(\mathrm{Cu})$ v nanodelcih cinkovega oksida $(\mathrm{ZnO})$ vpliva na energijsko vrzel ("band gap") in na selektivno citotoksičnost napram celicam raka dojke (MCF7), celicam raka materničnega vratu (HeLa) in napram normalnim celicam (Vero). Nanodelce $\mathrm{ZnO}$ dopirane $\mathrm{z} \mathrm{Cu}(\mathrm{Cu}-\mathrm{ZnO} N P s)$ smo sintetizirali in karakterizirali z UV-Vis spektroskopijo, infrardečo spektroskopijo (FT-IR), rentgensko praškovno difrakcijo (XRD), vrstično elektronsko mikroskopijo (SEM) in energijsko disperzijsko spektroskopijo rentgenskih žarkov (EDX). Energijska vrzel dopiranih nanodelcev $\mathrm{ZnO}$ se je zmanjšala iz 3,54 eV na 3,29 eV. Antimikrobno aktivnost smo ovrednotili napram trem bakterijskim in glivičnim sevom. Antioksidativno delovanje smo preučili z uporabo prostega radikala DPPH, radikalov $\mathrm{ABTS}^{+}$, hidroksilnih radikalov in radikalov dušikovega oksida. Rakave celice smo izpostavili nanodelcem in izmerili vrednosti $\mathrm{IC}_{50}: 219,56 \mu \mathrm{g} / \mathrm{ml}$ (MCF7) in 137,27 $\mu \mathrm{g} / \mathrm{ml}$ (HeLa). Dopirani nanodelci ZnO (Cu-ZnO NPs) imajo izboljšano selektivno citotoksičnost napram celicam MCF7 in HeLa, dopiranje pa ne vpliva na normalne celice. 